$\checkmark$ Research Square

\title{
Evaluation of six different protocols for protein extraction from rice young panicles by two- dimensional electrophoresis
}

Xiaoping Huang ( $\square$ xphuang940812@163.com )

Jiangxi Agricultural University

Hui-wen Zhou

Jiujiang University

\section{Research}

Keywords: Phenol, Proteomics, Rice, young panicles, Two-dimensional electrophoresis

Posted Date: March 12th, 2020

DOI: https://doi.org/10.21203/rs.3.rs-16995/v1

License: (c) (i) This work is licensed under a Creative Commons Attribution 4.0 International License.

Read Full License 


\section{Abstract}

Background: For most reported proteomics approaches, protein extraction are of crucial importance for optimal results. However, extraction of protein from plant tissues still exist great challenges due to low protein content and many secondary metabolites that prominently interfering with isoelectric focusing. Up to now, no attempts are focused on comparison of protein extraction from rice young panicles.

Methods: To establish a higher efficiency protein extraction protocol suited for two-dimensional electrophoresis in rice young panicles, six protocols for protein preparation were evaluated in terms of protein concentration, the molecular weight range of protein, gel image resolution, the number of protein spots: 1) Phenol extraction; 2) Mg/Nonidet P-40 (NP-40) extraction; 3) Tris-Base/acetone extraction; 4) SDS extraction; 5) trichloroacetic acid (TCA)/acetone/phenol extraction; 6) TCA/acetone precipitation.

Results: The result explicitly demonstrated that TCA/acetone/phenol method provided a high-enhanced protein extraction efficacy from rice young panicles than other protocols in terms of the protein concentration ( $9.79 \pm 0.23 \mathrm{SD}$ ), the most comprehensive proteins ( $10 \mathrm{KDa}$ to $150 \mathrm{KDa}$ ), the maximum number of protein spots ( $450 \pm 53 \mathrm{SD}$ ), the greater gel image resolution and spot abundance. In addition, these methods also generated remarkably differential 2-DE protein patterns. Twenty-nine of 30 visible differentially extracted proteins were identified by MS analysis and were divided into eight categories. Prediction for protein subcellular localization and grand average of hydropathy (GRAVY) analysis showed that certain special proteins respectively necessitate different extraction methods due to different physicochemical properties of each protocol.

Conclusions: Overall, this paper will facilitate to provide a cornerstone of comparative proteomic analysis from rice young panicles, including other complicated plant tissues.

\section{Background}

Over the last few decades, rapid advancements in high-resolution protein separation, mass spectrometry techniques and bioinformatics knowledge have led to an increasing application of proteomics to elucidate the underlying biology mechanisms [1]. Now, proteomics approaches integrated twodimensional electrophoresis (2-DE) with mass spectrometry (MS) has still proved to be the predominant technique [2-8], which was widely used in comparative proteomics studies, post-translational modifications and protein interaction network analysis [9-11].

Protein quality is unquestionably a crucial importance factor for better proteomics results involving the number of well-separated protein spots, reproducibility, resolution $[12,13]$, so protein extraction procedure is of extremely essential. The perfect protocol of protein extraction should reproducibly capture all most unprejudiced and comprehensive proteins from various tissues of different species while reducing contamination and minimizing degradation and modification. However, considering the diversity and specificity of sample tissues or species, no general and high-efficiency extraction protocol can capture the full proteome $[1,10,11]$. To date, tremendous efforts are more devoted to developing sample preparation 
protocols that could enhance plant proteomic analysis [14-17]. Nevertheless, plant proteomics analysis remains to be more troublesome challenges that are associated with large amounts of co-extraction of non-protein constituents, and comprehensive proteins are notoriously difficult to extract from plants, mostly due to having relatively low protein content and interfering compounds such as phenolic compounds, lipids, polysaccharides, proteolytic enzymes, oxidative enzymes and other secondary materials [18-22].

Currently, several reviews related to protein sample preparation have been published $[23,24]$. The most classical extraction tactics is TCA/acetone precipitation method followed by re-solubilization [25-27]. This protocol is suitable for various types of diverse plant tissues, including maize leaves [28, 29], tomato [30] and lucid ganoderma [31], but it was found to remain the inherent drawback that proteins may not completely resolubilize after precipitation. The merit of this protocol is that a precipitation procedure was proposed to concentrate proteins and eliminate interfering elements. An alternative phenol extraction protocol followed by ammonium acetate precipitation in methanol has been developed and was used successfully with grape [32], barely [33], olive leaf [34]. Furthermore, a combination of TCA/acetone and phenol method is also similarly confirmed to be very effective that provides enhanced 2-DE based proteomics analysis [12]. In addition, SDS extraction [10], Tris-Base/acetone precipitation [35-39] and $\mathrm{Mg} /$ Nonidet P-40 (NP-40) extraction [40] have also been reported in different tissues while not as frequently as the method mentioned above. Notoriously, how to select an appropriate protein extraction protocol mainly depends on the nature of plant tissues and on the downstream application. Considering this, there is an extremely urgent requirement for establishment of protein extraction protocols aimed at different tissues and species to facilitate comparative proteomics analyses.

Rice (Oryza sativa L.) is one of the major food consumed by more than half of the world's population. However, rice production was negatively influenced by various environmental stresses, including high temperature [41-43]. It was reported that exposure to high temperatures induced sterility, and rice was more sensitive to excessive heat especially in the young microspore period of booting stage [44]. To study changes at the proteomics level in rice young panicles in response to high temperature stress, the current work was performed to screen a suitable protein extraction protocol for subsequent proteomics analysis.

Thus, in this paper presented here, six protocols of protein extraction (phenol extraction, Mg/NP-40 extraction, Tris-Base/acetone extraction, SDS extraction, TCA/acetone precipitation, TCA/acetone/phenol extraction) were evaluated based on 1-DE maps, 2-DE maps and MS/MS analysis. To our best knowledge, this is the first study on comparison of protein extraction protocols from rice young panicles. Our results indicated that TCA/acetone/phenol method has the better efficacy of protein extraction and this evaluation will provide useful information for other rice tissues.

\section{Materials And Methods}

\subsection{Plant material}


Rice (Oryza sativa L. subsp. indica) was grown in paddy field at Jiangxi Agricultural University. Rice cultivation was essentially conducted by normal management way.

Rice young panicles in $7 \mathrm{~cm}$ length were sampled at booting stage (Fig. 1), packed in aluminum foil, flash-frozen in liquid nitrogen and stored at $-80^{\circ} \mathrm{C}$ for further proteomic protocols' evaluation.

\subsection{Six protocols for protein extraction}

Total protein from rice young panicles were extracted by six protocols including Phenol extraction, Mg/NP-40 extraction, Tris-Base/acetone extraction, SDS extraction, TCA/acetone/phenol extraction, TCA/acetone precipitation. Extraction procedure of each protocol was repeated three times. Frozen rice young panicles were pulverized to a fine powder in a pre-chilled mortar with liquid nitrogen. Later, the finely ground powder (three grams) was used for protein extraction. The six procedures for protein extraction as follows:

A) Phenol extraction in this study was performed according to Hurkman et al [33]. The powder was mixed with $15 \mathrm{~mL}$ protein extraction buffer ( $0.7 \mathrm{M}$ sucrose, $0.1 \mathrm{M} \mathrm{KCl}, 0.5 \mathrm{M}$ Tris-HCl (pH 7.5), $50 \mathrm{mM}$ EDTA, $2 \%$ v/v 2-mercaptoethanol (2-ME), $1 \% \mathrm{w} / \mathrm{v}$ PVPP), the homogenate was incubated for $30 \mathrm{~min}$ at $4^{\circ} \mathrm{C}$ with sharply vortexing every $10 \mathrm{~min}$. Then an equal volume of Tris-saturated phenol ( $\mathrm{pH} \mathrm{8.0)}$ was added into the above homogenate, and the formed mixture was incubated for $30 \mathrm{~min}$ at $4^{\circ} \mathrm{C}$. The formed mixture was cleared by centrifuged at $15000 \times \mathrm{g}$ for $30 \mathrm{~min}$ at $4^{\circ} \mathrm{C}$, the upper phenolic phase was collected and transferred into a clean $50 \mathrm{~mL}$ centrifuged tube followed by centrifugation. The collected phenolic phase was precipitated with five volumes of $0.1 \mathrm{M}$ ammonium acetate in methanol at $-20^{\circ} \mathrm{C}$ overnight and centrifuged as above. The precipitate was washed with cold acetone for three times. After each wash, the precipitate was centrifuged at $15000 \times \mathrm{g}$ for $30 \mathrm{~min}$ at $4^{\circ} \mathrm{C}$. The final precipitate was lyophilized, then fully dissolved in lysis buffer (7 M urea, $2 \mathrm{M}$ thiourea, $4 \% \mathrm{w} / \mathrm{v}$ CHAPS, $50 \mathrm{mM}$ DTT, $0.25 \% \mathrm{v} / \mathrm{v}$ carrier ampholytes, $\mathrm{pH} 3-10$ ) by water-bath heating at $28^{\circ} \mathrm{C}$ and stored at $-80^{\circ} \mathrm{C}$.

B) Mg/NP-40 extraction procedure in this paper was described by Kim et al [45]. The sample powder was transferred into a clean $50 \mathrm{~mL}$ centrifuge tube and then mixed with $15 \mathrm{~mL}$ pre-chilled protein extraction buffer (0.5 M Tris- $\mathrm{HCl}$ (pH 8.3), 2\% v/v NP-40, $20 \mathrm{mM} \mathrm{MgSO}_{4}, 2 \%$ v/v 2-ME, 1\% w/v PVPP). The homogenate was ultra-sonicated for $30 \mathrm{~min}$ at $4^{\circ} \mathrm{C}$ by Ultrasonic Cleaner (NingBo Scientz Biotech Co, China) before incubation for $1 \mathrm{~h}$ at $4^{\circ} \mathrm{C}$, and the homogenate was centrifuged at $15000 \times \mathrm{g}$ for $30 \mathrm{~min}$ at $4^{\circ} \mathrm{C}$. After centrifugation, the supernatant was collected, and then precipitated by adding four volumes of cold acetone ( $10 \% \mathrm{v} / \mathrm{v}$ TCA, $0.07 \% \mathrm{v} / \mathrm{v} 2-\mathrm{ME})$ at $-20^{\circ} \mathrm{C}$ overnight. Subsequently, protein pellet was obtained after centrifugation, the obtained protein pellet was resuspended in acetone with $0.07 \% \mathrm{v} / \mathrm{v} 2$ $\mathrm{ME}$ and incubated at $-20^{\circ} \mathrm{C}$ for $1 \mathrm{~h}$, and then centrifuged at $15000 \times \mathrm{g}$ for $30 \mathrm{~min}$ at $4^{\circ} \mathrm{C}$. Later, the protein pellet was repeatedly washed with cold acetone $(0.07 \% \mathrm{v} / \mathrm{v} 2-\mathrm{ME})$ for three times. After each wash, the protein pellet was centrifuged at $15000 \times \mathrm{g}$ for $30 \mathrm{~min}$ at $4^{\circ} \mathrm{C}$. The final protein pellet was lyophilized, then fully dissolved in lysis buffer (7 M urea, $2 \mathrm{M}$ thiourea, 4\% w/v CHAPS, $50 \mathrm{mM} \mathrm{DTT,} \mathrm{0.25 \%} \mathrm{v/v} \mathrm{carrier}$ ampholytes, $\mathrm{pH} 3-10$ ) by water-bath heating at $28^{\circ} \mathrm{C}$ and stored at $-80^{\circ} \mathrm{C}$. 
C) Tris-Base/acetone extraction was based on a previously method published by Zhang et al [36]. The powder was transferred into a clean $50 \mathrm{~mL}$ centrifuge tube and mixed with $15 \mathrm{~mL}$ extraction buffer (50 $\mathrm{mM}$ Tris- $\mathrm{HCl}$ (pH 7.5), $50 \mathrm{mM}$ EDTA, $100 \mathrm{mM} \mathrm{KCl,} 20 \mathrm{mM}$ DTT, 1\% w/v PVPP). The homogenate was fully vortexed for $1 \mathrm{~min}$ and ultra-sonicated for $30 \mathrm{~min}$ at $4{ }^{\circ} \mathrm{C}$ by Ultrasonic Cleaner (NingBo Scientz Biotech Co, China) before incubation for $1 \mathrm{~h}$ at $4^{\circ} \mathrm{C}$. After centrifugation $\left(15000 \times \mathrm{g}, 30 \mathrm{~min}, 4^{\circ} \mathrm{C}\right)$, the supernatant was treated as described above in "Mg/NP-40 extraction".

D) SDS extraction was adapted from Zhen et al [10]. The powder was homogenized in $15 \mathrm{~mL}$ lysis buffer ( $2 \% \mathrm{w} / \mathrm{v}$ SDS, $5 \% \mathrm{w} / \mathrm{v}$ sucrose, $0.6 \% \mathrm{w} / \mathrm{v}$ PVPP, $0.3 \% \mathrm{w} / \mathrm{v}$ DTT, $20 \mathrm{mM}$ sodium phosphate, $\mathrm{pH} 7.0$ ) and incubated at $65^{\circ} \mathrm{C}$ for $20 \mathrm{~min}$. The homogenate was cooled at $4^{\circ} \mathrm{C}$ prior to centrifugation at $15000 \times \mathrm{g}$ at $4^{\circ} \mathrm{C}$ for $30 \mathrm{~min}$. Then supernatant was treated as described above in "Mg/NP-40 extraction".

E) The new protocol integrating TCA/acetone precipitation with phenol extraction was adapted from Isaacson et al [1]. The sample powder was homogenized in $15 \mathrm{~mL}$ cold acetone $(10 \% \mathrm{w} / \mathrm{v} \mathrm{TCA}, 0.07 \% \mathrm{v} / \mathrm{v}$ 2-ME) at $-20^{\circ} \mathrm{C}$ overnight, followed by centrifugation at $15000 \times \mathrm{g}$ at $4^{\circ} \mathrm{C}$ for $30 \mathrm{~min}$. The obtained precipitate was rinsed with acetone and incubated for $1 \mathrm{~h}$ at $-20^{\circ} \mathrm{C}$ for three times. After each wash, the precipitate was centrifuged at $15000 \times \mathrm{g}$ for $30 \mathrm{~min}$ at $4^{\circ} \mathrm{C}$. Subsequently, the final protein precipitate was lyophilized and treated as described above in "phenol extraction".

F) The protein extraction protocol was a classical TCA/acetone precipitation procedure adapted from Damerval et al [25] with some modifications. The sample powder was homogenized in $15 \mathrm{~mL}$ cold acetone $(10 \% \mathrm{w} / \mathrm{v}$ TCA, $0.07 \% \mathrm{v} / \mathrm{v} 2-\mathrm{ME})$ at $-20^{\circ} \mathrm{C}$ overnight, followed by centrifugation at $15000 \times \mathrm{g}$ at $4^{\circ} \mathrm{C}$ for $30 \mathrm{~min}$. The obtained precipitate was rinsed with acetone and incubated for $1 \mathrm{~h}$ at $-20^{\circ} \mathrm{C}$, then was filtered by medical gauze and centrifuged. The purification step above was repeated for three times until white protein pellet was obtained and supernatant was colorless. After each wash, the precipitate was centrifuged at $15000 \times \mathrm{g}$ for $30 \mathrm{~min}$ at $4^{\circ} \mathrm{C}$. Finally, the white protein pellet was lyophilized, then fully dissolved in lysis buffer (7 M urea, $2 \mathrm{M}$ thiourea, 4\% w/v CHAPS, $50 \mathrm{mM}$ DTT, $0.25 \% \mathrm{v} / \mathrm{v}$ carrier ampholytes, $\mathrm{pH} 3-10$ ) by water-bath heating at $28^{\circ} \mathrm{C}$ and stored at $-80^{\circ} \mathrm{C}$.

\subsection{Total protein quantification}

The lyophilized protein pellet was fully dissolved in lysis buffer ( $7 \mathrm{M}$ urea, $2 \mathrm{M}$ thiourea, $4 \% \mathrm{w} / \mathrm{v}$ CHAPS, $50 \mathrm{mM}$ DTT, $0.25 \% \mathrm{v} / \mathrm{v}$ carrier ampholytes, $\mathrm{pH} 3-10$ ) by water-bath heating at $28^{\circ} \mathrm{C}$ and the concentration of total protein was determined by Bradford assay [45], using bovine serum albumin as calibration standard protein.

\subsection{One dimensional SDS-PAGE}

To evaluate the integrity of total protein and visible differences of protein concentrations, $36 \mu \mathrm{g}$ and $2 \mu \mathrm{L}$ of each protein sample extracted by six protocols was separated by one dimensional SDS-PAGE, respectively. Briefly, the total protein was separated on $12.5 \% \mathrm{w} / \mathrm{v}$ SDS-PAGE gel and $5 \% \mathrm{w} / \mathrm{v}$ stacking gel. Electrophoresis was performed at $80 \mathrm{~V}$ until the dye traversed the stacking gel, followed by $120 \mathrm{~V}$ until the 
dye front reached the bottom of the SDS-PAGE gel. Gels were stained with Coomassie brilliant blue G-250 (CBB G-250) and silver stained as previously described [46], then gels were kept in $30 \%$ glycerol.

\subsection{Two-dimensional electrophoresis}

Firstly, a total of $250 \mu \mathrm{g}$ each protein sample was mixed with corresponding volume rehydration buffer (7 M urea, $2 \mathrm{M}$ Thiourea, 1.2\% w/v CHAPS, 0.005\% w/v Bromophenol blue, $20 \mathrm{mM}$ DTT, 0.25\% v/v carrier ampholytes, $\mathrm{pH}$ 3-10) and dissolved at room temperature for at least $1 \mathrm{~h}$. The mixed buffer (including rehydration buffer and $250 \mu \mathrm{g}$ total protein sample) was centrifuged at $15000 \times \mathrm{g}$ at $4^{\circ} \mathrm{C}$ for $15 \mathrm{~min}$ and the immobilized linear pH gradient (IPG) strips $(24 \mathrm{~cm}, \mathrm{pH} 3-10)$ thawed at room temperature for $15 \mathrm{~min}$. Then the IPG strips were rehydrated for $14 \mathrm{~h}$ in $450 \mu \mathrm{L}$ mixed buffer, and isoelectric focusing was carried out using PROTEAN i12 IEF cell system (Bio-Rad, USA) at $20^{\circ} \mathrm{C}$, applying the following procedure: $100 \mathrm{~V}$ rapid for $1.5 \mathrm{~h}, 200 \mathrm{~V}$ rapid for $1.5 \mathrm{~h}, 500 \mathrm{~V}$ rapid for $1.5 \mathrm{~h}, 1000 \mathrm{~V}$ rapid for $1.5 \mathrm{~h}, 5000 \mathrm{~V}$ rapid for $1 \mathrm{~h}$, $10000 \mathrm{~V}$ gradual for $1 \mathrm{~h}$, and until $135000 \mathrm{VH}$ with a maximum voltage of $10000 \mathrm{~V}$. Prior to second dimension analysis, the strips were reduced for $15 \mathrm{~min}$ in $10 \mathrm{~mL}$ equilibration buffer $(6 \mathrm{M}$ urea, $2 \% \mathrm{w} / \mathrm{V}$ SDS, $20 \%$ v/v glycerol, $50 \mathrm{mM}$ Tris, pH 8.8) containing $2 \% \mathrm{w} / \mathrm{v}$ DTT and subsequently alkylated for 15 min in $10 \mathrm{~mL}$ equilibration buffer containing $2.5 \% \mathrm{w} / \mathrm{v}$ iodoacetamide. Finally, the strips were transferred to $12.5 \% \mathrm{w} / \mathrm{v}$ SDS-PAGE gels and further sealed with $1 \% \mathrm{w} / \mathrm{v}$ low-melting agarose solution. The second dimension electrophoresis was performed at $100 \mathrm{~V}$ using PROTEAN Plus Dodeca cell system (Bio-Rad, USA) until the dye began enter into gel, followed by constant voltage of $170 \mathrm{~V}$ until the dye front reached the bottom of the gel. Then the gels were silver stained as established by Liao et al [46, 47], and gels were kept in $30 \%$ glycerol.

\subsection{Gel images acquisition and analysis}

All stained gel images were captured by GS-800 calibrated imaging densitometer (Bio-Rad, USA) with transmission-mode at $600 \mathrm{dpi}$ and saved as "TIFF" format. The gel images were analyzed by Quantity One software and Image Master 2D PDQuest 8.0 software (Bio-Rad; USA), respectively. Briefly, the number of protein bands per lane and molecular weight were detected by Quantity One software, and the number of protein spots and abundance automatically detected by PDQuest software. At the same time, in order to compare the types of proteins extracted by various procedures, visible proteins which existed in either one protocol or less than six protocols were considered to be differentially extracted proteins and marked in the gel images by arrows. Then, the data including protein concentrations and the number of protein spots, was statistically evaluated by one-way analyses of variance (ANOVA) to determine the significant difference among extraction methods using SPSS version 17.0 software. In all cases, significance was defined as $p<0.05$. The repeated measurement was given as means \pm standard deviation (SD).

\subsection{Protein digestion}

For protein digestion, visible differentially extracted protein spots were excised out of the gels and transferred into clean $1.5 \mathrm{~mL}$ centrifuge tubes. Protein spots were repeatedly washed twice with deionized water, and then destained with $30 \% \mathrm{v} / \mathrm{v}$ acetonitrile solution $\left(15 \mathrm{mM} \mathrm{K}_{3} \mathrm{Fe}(\mathrm{CN})_{6}, 50 \mathrm{mM} \mathrm{Na} \mathrm{S}_{2} \mathrm{O}_{3}\right)$ at $37^{\circ} \mathrm{C}$ 
for 30 min. After removal of the destaining solution, protein spots were washed twice again, and dehydrated with acetonitrile (ACN) for 30 min until protein spots completely appeared white.

Subsequently, protein spots were digested for $16 \mathrm{~h}$ at $37^{\circ} \mathrm{C}$ in $20 \mu \mathrm{L}$ of $0.02 \mu \mathrm{g} / \mu \mathrm{L}$ trypsin solution ( $10 \%$ v/v ACN, $25 \mathrm{mM} \mathrm{NH}_{4} \mathrm{HCO}_{3}$ ) as previously described by Liao et al[47, 48]. After centrifugation, the supernatant were transferred into another tube, and the undissolved gel particles were further extracted by extraction solution ( $5 \% \mathrm{v} / \mathrm{v}$ trifluoroacetic acid (TFA), $67 \% \mathrm{v} / \mathrm{v}$ ACN) at $37^{\circ} \mathrm{C}$ for $30 \mathrm{~min}$. Finally, the extracts and the supernatant were pooled and then lyophilized. The lyophilized protein samples were kept at $-80^{\circ} \mathrm{C}$ until MS analysis.

\subsection{Protein identification by MS analysis}

For MALDI-TOF-MS/MS analysis, the lyophilized protein samples were dissolved in $5 \mu \mathrm{L}$ of $0.1 \% \mathrm{v} / \mathrm{v}$ TFA solution, and mixed (1:1, v/v) with Matrix solution (a-cyano-4-hydroxycinnamic-acid in $50 \% \mathrm{v} / \mathrm{v}$ ACN and $0.1 \% \mathrm{v} / \mathrm{v}$ TFA). Then $1 \mu \mathrm{L}$ of the mixture samples were spotted on a stainless steel sample target plate, the peptide were further performed using the ABI 5800 MALDI-TOF/TOF Plus mass spectrometer, a matrixassisted laser desorption ionization time of flight mass spectrometer (Applied Biosystems, USA).

MS data was acquired over a mass range of 800-3500 Da in positive ion reflector mode and data independent acquisition mode, with an accelerating voltage of $20 \mathrm{kV}$. MS was used a CalMix 5 standard to calibrate the instrument (ABI 5800 Calibration Mixture). For MS data accuracy, autolysis peaks of trypsin were used as internal calibration. And for MS/MS data acquisition, up to 10 of the most intense ion signals were selected as precursors in positive ion mode, excluding the trypsin autolysis peaks and the matrix ion signals. Both the MS and MS/MS data were integrated and processed by using the GPS Explorer V3.6 software (Applied Biosystems, USA) with default parameters. Peptides were identified in the NCBInr database/UniportKB database using MASCOT Version 2.3 search engine (Matrix Science, London, UK).

The following parameters were used for searching: 1) a maximum of one missed tryptic cleavage; 2) allowed a fixed modification of cysteine carbamidomethylation; 3 ) possible variable modification of oxidation at methionine; 4) precursor ion tolerance of $100 \mathrm{ppm}$; 5) MS/MS tolerance of $0.3 \mathrm{Da}$; 6) taxonomy restrictions to rice. Protein spots were considered to be successfully identified based on $95 \%$ or higher confidence interval of MS/MS data score (score $>40$ ). Finally, the identified proteins were classified according to its annotated functions.

\subsection{Prediction methods}

To evaluate solubilization of proteins, the grand average of hydropathy index (GRAVY) was obtained using the ProtParam Tool (https://web.expasy.org/protparam/). Predictions for protein subcellular localization were performed by UniProtKB and WOLF PSORT Prediction (https://www.genscript.com/tools/wolf-psort).

\section{Results And Discussion}




\subsection{Quantitative comparison of protein concentrations}

The concentrations of total proteins $(\mu \mathrm{g} / \mu \mathrm{L})$ were shown in Table 1 and were $13.59 \pm 0.057$ for phenol extraction, $13.02 \pm 0.61$ for Mg/NP-40 extraction, $10.89 \pm 0.46$ for Tris-Base/acetone extraction, $10.76 \pm 0.17$ for SDS extraction, $9.79 \pm 0.23$ for TCA/acetone/phenol extraction, $5.93 \pm 0.22$ for TCA/acetone precipitation. Quantitative comparisons of proteins extracted from rice young panicles revealed that phenol extraction showed no statistically significantly total protein concentration difference compared with Mg/NP-40 extraction, but the two methods above gave statistically significantly greater concentrations than other methods.

Exhilaratingly, a giant result was obtained from rice young panicles than other plants tissue by using TCA/acetone precipitation $(5.93 \pm 0.22 \mu \mathrm{g} / \mu \mathrm{L})$ and Tris-Base/acetone precipitation $(10.89 \pm 0.46 \mu \mathrm{g} / \mu \mathrm{L})$, which greatly facilitate to gaining better 2-DE patterns $[49,50]$.

\subsection{One dimensional SDS-PAGE evaluation of six protocols}

The total proteins were separated by one dimensional SDS-PAGE, gels were stained with CBB G-250 and silver stained, respectively. Representative gel images from replicated experiments were shown in Fig 2.

Firstly, comparison of two staining protocols revealed that G-250 staining protocol has better image resolution, more detected bands (Table 1), despite higher sensitivity in silver staining. Then, quality characteristics of protein bands per lane presumably reflected contaminants contents from each protocol of protein extraction that as assessed by resolution. And the total proteins were resolved into clear bands varing from $10 \mathrm{KDa}$ to more than $150 \mathrm{KDa}$ by Quantity One software analysis (Fig 2). Both the sample of Mg/NP-40 extraction and TCA/acetone/phenol extraction commonly showed a greater extent of smearing in the higher molecular weight (MW) regions of the gels that may cause by the presence of nucleic acid, because viscous and stringy protein sample were observed to load into the well in our experiments. The sample of Tris-Base/acetone extraction typically contained fewest higher MW proteins similar to that SDS extraction. Exceptionally, the sample of TCA/acetone precipitation has a maximum number of high MW protein bands by Quantity One software analysis. The phenol extraction and TCA/acetone precipitation generated apparently greater quality protein samples in terms of well-resolved bands, no smearing, better background, no redundant materials in the wells.

Many protein determination methods including Bradford assay, Lowry assay and UV spectroscopy, which were used to assess protein concentration, nevertheless no single assay could yield absolutely accurate results [51]. In this study, accordingly, contrary results of SDS-PAGE gel patterns between TCA/acetone precipitation and SDS extraction suggested that the existence of some contaminants would skew the accuracy of sample loading.

Finally, the most obvious difference was visualized that the sample of TCA/acetone/phenol extraction provided the most comprehensive polypeptides comparing with other samples. Interestingly, approximately $55 \mathrm{KDa}$ of the large subunit of certain protein in current study similar to ribulose 
bisphosphate decarboxylase/oxygenase (Rubisco) was appeared here indicated by an arrow. It is all known to that Rubisco is arguably considered to be the most abundant protein and can make up the majority of total leaf protein. And many efforts have been developed to remove Rubisco, because itself will greatly decrease the number of detectable protein spots during 2-DE [52, 53]. Up to now, no extraction protocol has focused on how to avoid this problem, but phenol-based method could acquire high quality protein sample and simultaneously reduce contents of Rubisco described by Saravanan [12].

\subsection{Two-dimensional electrophoresis evaluation of six protocols}

The total proteins respectively extracted by six protocols from rice young panicles were separated by 2-DE and all gels were silver stained (Fig 3). The six protocols for protein extraction gave hundreds of protein spots (Table 1) and different resolution, which were discussed in details below.

In this study, TCA/acetone/phenol extraction gave satisfactory results with the maximum number of

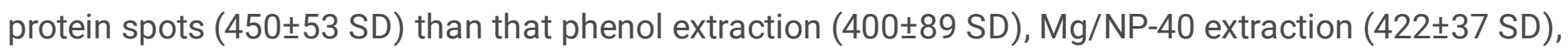
Tris-Base/acetone extraction ( $424 \pm 66$ SD), SDS extraction (287 \pm 31 SD) and TCA/acetone precipitation (321 \pm 17 SD). Especially, TCA/acetone/phenol extraction showed the best image resolution including well-resolved protein spots, minimum background staining and horizontal stripes. Obvious differences were also observed in the spot patterns that the abundance of same protein spots extracted by TCA/acetone/phenol protocol was higher than the others (Fig 4).

First, the three commonly used methods: phenol extraction, TCA/acetone/phenol extraction and TCA/acetone precipitation were analyzed in details. Phenol extraction method originally described by Meyer and Hurkman [33, 54] was further developed with making some modifications $[14,19,34,55]$. For example, some methodologys added sucrose into aqueous buffer to create that aqueous phase has greater density than phenol phase [33]. To some extent, the best merit of phenol extraction was very efficient for producing superior protein sample by allowing removal of polysaccharides and nucleic acids with the enzyme inactivation than other methods due to the utilization of phenol. Nonetheless, some limitations still exist here that it is toxic, time-consuming and not able to produce high-quality 2-DE profiles in special recalcitrant tissues from various species.

Besides, in this paper, classical TCA/acetone precipitation produce few protein spots ( $321 \pm 17$ SD) and poor resolution including streaking and smearing, mainly because the precipitated pellets were difficult to dissolve, and multiple washing step caused protein losses, which was not considered to be favored in complex plant tissues.

Considering this potential challenge, a new protocol integrated TCA/acetone precipitation with phenol extraction, which was used for protein sample preparation from recalcitrant plant tissues described by Wang $[18,19]$. Our results including the number of protein spots (450 \pm 53 SD) and image resolution were similar to the majority of previously reported papers, which showed TCA/acetone/phenol protocol was sufficient to produce higher quality profiles than either TCA/acetone precipitation or phenol extraction alone, and could provide an enhanced 2-DE based proteomic analysis [9, 21]. 
The confused fact was that the three methods of SDS extraction, Mg/NP-40 extraction, Tris-Base/acetone extraction created fairish effect whereas few reports were published. SDS extraction was designed for total protein preparation similar to TCA/acetone precipitation, which the biggest difference between both methods was that the use of SDS anionic detergent. It has been reported that SDS possessed to an ability of highly bind protein at an increased temperature of $95^{\circ} \mathrm{C}$, which can improve the solubilization of membrane proteins [3].

In this paper, SDS extraction produces the fewest number of protein spots $(287 \pm 31$ SD). We speculated that heating may cause protein degradation and then the utilization of anionic surfactants may cause proteins to precipitate in IEF gels $[3,55]$. Contrast to the poor result of SDS extraction, Mg/NP-40 extraction gave more well-separated protein spots (422 \pm 37 SD) with application of nonionic surfactant NP-40 which may reduce extraction of ribulose bisphosphate decarboxylase/oxygenase [56]. However, membrane proteins might be sparingly soluble, especially the existence of NP-40 detergent [57]. Therefore, in this study, the gel image of Mg/NP-40 extraction showed a slightly inferior resolution including high background staining (Fig. 4B). The last protocol to describe was Tris-Base/acetone extraction, which existed remarkable difference in the number of protein spots ( $424 \pm 66 \mathrm{SD}$ ) whereas no significant difference in protein concentration compared with SDS extraction. We kept extraction buffer $\mathrm{pH} 7.5$ to assure that large amounts of phenolic substances are mainly ionized and $\mathrm{H}$ not binding with proteins. Finally, we obtained a better image resolution and more protein spots, which were confirmed to be very effective compared with previously published paper [58].

\subsection{Protein identification}

Thirty differential extracted protein spots were excised out of the gels and were subjected to MALDI-TOFMS/MS analysis. Protein identification was accomplished by searching against the NCBInr database and Uniport database with MASCOT software. Twenty-nine of 30 selected differential extracted protein spots were identified and the identification results were shown in Table 2.

However, the identified protein spot 6 (gi|2058273, 60S ribosomal protein L9), spot 7 (gi|39545864, OSJNba0093F12.16 protein), spot 23 (gi|20188, calmodulin) and the corresponding spot 9 , spot 8 , spot 25 were the same protein spots, respectively. Interestingly, spot 18 (gi|29467522, cold shock domain protein 2), spot 19 (gil46805895, 4-hydroxy-4-methyl-2-oxoglutaratealdolase), spot 20 (gi|22831338, actin-depolymerizing factor 9), spot 22 (gi|50725625, putative acidic ribosomal protein P1a), spot 26 (gi|29367559, putative serine/threonine kinase), spot 27 (gi|55296630, putative profilin), spot 28 (gi|5360221, nuclear transport factor 2), spot 29 (gi|47497145, cytochrome b5 domain-containing proteinlike) and spot 30 (gi|28564644, putative Acyl-CoA binding protein) were both presented in phenol extraction protocol and TCA/acetone/phenol extraction protocol. Spot 21 (gi|485953, Glutaredoxin-C6), and spot 24 (gi|3603473, Elicitor-responsive protein 3) only presented in TCA/acetone/phenol protocol. And spot 24 was an elicitor-responsive gene, which might play an important role in responding to environment stress. Furthermore, two mitochondrial outer membrane protein porin5, spot 1(gi|29367429) and spot 2 (gi|18076158) were only just not presented in Tris-base/acetone extraction protocol. Finally, 
functions of the identified proteins were annotated and classified into eight categories involving in oxidation, defense response, photosynthesis, biosynthesis, transcriptional regulation, transportion and signal transduction, translation, unknown protein (Table 2).

\subsection{Explanation for differential extraction}

Each protocol of protein extraction had its preference for extracting special proteins [59]. Therefore we speculated that a possible explanation for the differences were some cellular substances were more effectively disrupted by other multiple protocols and then were released. To validate this idea, predictions for protein subcellular localization were performed by UniProtKB and WoLF PSORT Prediction. Prediction results indicated that spot 1 (gi|29367429), spot 2 (gi|18076158), spot 18 (gi|29467522) were located in mitochondria, spot 12 (gil18461185), spot 15 (gil108707099), spot 23 (gi|20188) were located in nucleus, spot 4 (gil11955) was located in chloroplast, other 22 protein spots were located in cytoplasm, so the conclusion was made that proteins presented in all organelles was almost easily extracted by phenolbased method.

The second explanation for the differences was hydropathicity of proteins, because hydropathicity played a critical role in the solubilization of proteins. A widely used method for predicting hydropathicity was the calculation of GRAVY [34]. The GRAVY value of the identified proteins ranges from - 0.724 to 0.181 (Table 2) and only three positive GRAVY values (spot 19, gi|46805895; spot 21, gi|485953; spot 22, gi|50725625) were obtained. Simultaneously, the three proteins with positive GRAVY value were obtained by phenol extraction and TCA/acetone/phenol extraction. Thus, we concluded that phenol-based protocols more simply extracted hydrophobic proteins.

\section{Conclusions}

In summary, we evaluated six protocols for protein extraction based on the protein concentrations, the molecular weight range of proteins, image resolution and the number of protein spots. The accumulated data showed in this study presented here that TCA/acetone/phenol protocol provided the best extraction efficacy from rice young panicles.

It depended on the fact that TCA/acetone/phenol protocol integrated the merits of both TCA/acetone precipitation, which actually could eliminate non-protein substance, and phenol extraction, which purposefully could dissolve water-soluble proteins and non-water-soluble proteins, to facilitate effective purification for crop plants. And it was worth noting that visible value of detecting greater amounts of protein spots far outweighed the little extra labor investment in sample preparation, although it was sometimes described as toxic and with more time consuming nature. Finally, we expected that this paper will facilitate to providing useful information for protein extraction of other rice tissues.

\section{Declarations}

\section{Acknowledgments}


Not applicable

\section{Funding}

This work was supported by the National Natural Science Foundation of China (grant numbers: 31860359).

\section{Author information}

\section{Affiliations}

Key Laboratory of Crop Physiology, Ecology and Genetic Breeding (Jiangxi Agricultural University), Ministry of Education of the P.R. China, Nanchang 330045, Jiangxi Province, China

Xiaoping Huang

2 College of Pharmacy and Life Science, Jiujiang University, Jiujiang City, Jiangxi Province, 332005, China

Huiwen Zhou

\section{Contributions}

$\mathrm{XH}$ finished the experiment and draft the manuscript. $\mathrm{HZ}$ participated in the discussions.

\section{Corresponding author}

Correspondence to Xiaoping Huang

\section{Ethics declarations}

\section{Ethics approval and consent to participate}

Not applicable.

\section{Consent for publication}

Not applicable.

\section{Competing interests}

The authors declare that they have no competing interests.

\section{References}

[1]Isaacson T, Damasceno C M B, Saravanan R S, He Y, Catalá C, Saladié M, Rose J K, Sample extraction techniques for enhanced proteomic analysis of plant tissues. Nat Protoc 2006, 1, 769-74. 
[2]O'Farrell P H, High resolution two-dimensional electrophoresis of proteins. J Biol Chem 1975, 250, 4007-21.

[3]Görg A, Weiss W, Dunn M J, Current two-dimensional electrophoresis technology for proteomics. Proteomics 2004, 4, 3665-3685.

[4]Fenn J B, Mann M, Meng C K, Wong S F, Whitehouse C M, Electrospray ionization for mass spectrometry of large biomolecules. Science 1989, 246, 64-71.

[5]Jiang Z, Kumar M, Padula M P, Pernice M, Kahlke T, Kim M, Ralph P J, Development of an Efficient Protein Extraction Method Compatible with LC-MS/MS for Proteome Mapping in Two Australian Seagrasses Zostera muelleri and Posidonia australis. Front Plant Sci 2017, 8, 1416.

[6]Giribaldi M, Perugini I, Sauvage F X, Schubert A, Analysis of protein changes during grape berry ripening by 2-DE and MALDI-TOF. Proteomics 2007, 7, 3154-70.

[7]Lee D Y, Kind T, Yoon Y R, Fiehn O, Liu K H, Comparative evaluation of extraction methods for simultaneous mass-spectrometric analysis of complex lipids and primary metabolites from human blood plasma. Anal Bioanal Chem 2014, 406, 7275-86.

[8]Hesselager M O, Codrea M C, Bendixen E, Evaluation of preparation methods for MS-based analysis of intestinal epithelial cell proteomes. Proteomics 2015, 15, 2350-7.

[9]Maldonado A M, Echevarría-Zomeño S, Jean-Baptiste S, Hernández M, Jorrín-Novo J V, Evaluation of three different protocols of protein extraction for Arabidopsis thaliana leaf proteome analysis by twodimensional electrophoresis. J Proteomics 2008, 71, 461-72.

[10]Zhen Y, Shi J, Evaluation of sample extraction methods for proteomic analysis of coniferous seeds. Acta Physiol Plant 2011, 33, 1623-1630.

[11]Wongpia A, Mahatheeranont S, Lomthaisong K, Niamsup H, Evaluation of Sample Preparation Methods from Rice Seeds and Seedlings Suitable for Two-Dimensional Gel Electrophoresis. Appl Biochem and Biotech 2015, 175, 1035-1051.

[12]Saravanan R S, Rose J K C, A critical evaluation of sample extraction techniques for enhanced proteomic analysis of recalcitrant plant tissues. Proteomics 2004, 4, 2522-32.

[13]Wang W, Tai F, Chen S, Optimizing protein extraction from plant tissues for enhanced proteomics analysis. J Sep Sci 2008, 31, 2032-9.

[14]Wang W, Scali M, Vignani R, Spadafora A, Sensi E, Mazzuca S, Cresti M, Protein extraction for twodimensional electrophoresis from olive leaf, a plant tissue containing high levels of interfering compounds. Electrophoresis 2003, 24, 2369-2375. 
[15]Kersten B, Bürkle L, Kuhn E J, Giavalisco P, Konthur Z, Lueking A, Walter G, Eickhoff H, Schneider U, Large-scale plant proteomics. Plant Mol Biol 2002, 48, 133-141.

[16]Li D J, Deng Z, Chen C L, Chen S C, Research Progress on Protein Extraction from Plant Tissues for Two-dimensional Gel Electrophoresis. Chinese Agricultural Science Bulletin 2009, 24, 78-82.

[17]Laing W, Christeller J, Extraction of proteins from plant tissues. Curr Protoc Protein Sci 2004, 4, Unit 47.

[18]Wang W, Vignani R, Scali M, Cresti M, A universal and rapid protocol for protein extraction from recalcitrant plant tissues for proteomic analysis. Electrophoresis 2006, 27, 2782-2786.

[19]Wu X, Xiong E, Wang W, Scali M, Cresti M, Universal sample preparation method integrating trichloroacetic acid/acetone precipitation with phenol extraction for crop proteomic analysis. Nat Protoc $2014,9,362-74$.

[20]Canovas F M, Dumas-Gaudot E, Recorbet G, Jorrin J, Mock H P, Rossignol M, Plant proteome analysis. Proteomics 2004, 4, 285-98.

[21]Jorrin J.V, Maldonado A M, Castillejo M A, Plant proteome analysis: a 2006 update. Proteomics 2007, 7, 2947-62.

[22]Agrawal G K, Jwa N, Iwahashi Y, Yonekura M, Iwahashi H, Rakwal R, Rejuvenating rice proteomics: Facts, challenges, and visions. Proteomics 2006, 6, 5549-5576.

[23]Rose J K C, Bashir S, Giovannoni J J, Jahn M M, Saravanan R, Subramanian, Tackling the plant proteome: practical approaches, hurdles and experimental tools. The Plant Journal 2004, 39, 715-733.

[24]T imperio A M, Egidi M G, Zolla L, Proteomics applied on plant abiotic stresses: role of heat shock proteins (HSP). J Proteomics 2008, 71, 391-411.

[25]Damerval C, de Vienne D, Zivy M, Thiellement H, Technical improvements in two-dimensional electrophoresis increase the level of genetic variation detected in wheat-seedling proteins. Electrophoresis $1986,7,52-54$.

[26]Rabilloud T, Use of thiourea to increase the solubility of membrane proteins in two-dimensional electrophoresis. Electrophoresis 1998, 19, 758-60.

[27]Santoni V, Bellini C, Caboche M, Use of two-dimensional protein-pattern analysis for the characterization of Arabidopsis thaliana mutants. Planta 1994, 192, 557-566.

[28]Benes `ova' M, Hola' D, Fischer L, Jedelsky' P L, Hnilic `ka F, Wilhelmova' N, Rothova' O, Koc`ova' M, Procha'zkova' D, Honnerova' J, Fridrichova' L, Hnilic `kova' H, The physiology and proteomics of drought 
tolerance in maize: early stomatal closure as a cause of lower tolerance to short-term dehydration? Plos One 2012, 6, e38017.

[29]Amiour N, Imbaud S, Clement G, Agier N, Zivy M, Valot B, Balliau T, Armengaud P, Quillere I, Canas R, Tercet-Laforgue T, Hirel B, The use of metabolomics integrated with transcriptomic and proteomic studies for identifying key steps involved in the control of nitrogen metabolism in crops such as maize. $J$ Exp Bot 2012, 63, 5017-33.

[30]Vilhena M B, Franco M R, Schmidt D, Carvalho G, Azevedo R A, Evaluation of protein extraction methods for enhanced proteomic analysis of tomato leaves and roots.

Anais da Academia Brasileira de Ciências 2015, doi.org/10.1590/0001-3765201520150116.

[31]Al-Obaidi J R, Saidi N B, Usuldin S R A, Hussin S N I, Said, Yusoff N M, Idris A S, Comparison of Different Protein Extraction Methods for Gel-Based Proteomic Analysis of Ganoderma spp. Protein J $2016,35,100-106$.

[32]Vincent $D$, Wheatley M D, Cramer G R, Optimization of protein extraction and solubilization for mature grape berry clusters. Electrophoresis 2006, 27, 1853-1865.

[33]Hurkman W J, Tanaka C K, Solubilization of plant membrane proteins for analysis by twodimensional gel electrophoresis. Plant Physio/ 1986, 83, 802-6.

[34]Carpentier S C, Witters E, Laukens K, Deckers P, Swennen R, Panis B, Preparation of protein extracts from recalcitrant plant tissues: An evaluation of different methods for two-dimensional gel electrophoresis analysis. Proteomics 2005, 5, 2497-507.

[35]Pang X H, Zhang Y, Huang G D, Huang Q, Comparison of protein extraction methods from leaves inClausena lansium. Noonwood Forest Reaearch 2017, 35, 59-63.

[36]Zhang Y, Xu L, Zhu X, Gong X, Xiang F, Sun X, Liu L, Proteomic Analysis of Heat Stress Response in Leaves of Radish (Raphanus sativus L.). Plant Mol Biol Rep 2013, 31, 195-203.

[37]Xiang X, Ning S, Jiang X, Gong X, Zhu R, Zhu L, Wei D, Protein extraction from rice (Oryza sativa L.) root for two-dimensional electrophoresis. Frontiers of Agriculture in China 2010, 4, 416-421.

[38]Sheoran I S, Ross A R S, Olson D J H, Sawhney V K, Compatibility of plant protein extraction methods with mass spectrometry for proteome analysis. Plant Sci 2009, 176, 99-104.

[39]Soundararajan P, Manivannan A, Ko C H, Jeong B R, Silicon Enhanced Redox Homeostasis and Protein Expression to Mitigate the Salinity Stress in Rosa hybrida 'Rock Fire'. J Plant Growth Regul 2017, DOI 10.1007/s00344-017-9705-7. 
[40]Yang P, Chen H, Liang Y, Shen S, Proteomic analysis of de-etiolated rice seedlings upon exposure to light. Proteomics 2007, 7, 2459-2468.

[41]Jagadish S, Craufurd P Q, Wheeler T R, High temperature stress and spikelet fertility in rice (Oryza sativa L.). J Exp Bot 2007, 58, 1627-1635.

[42]Cao Y, Duan H, Yang L, Wang Z, Zhou S, Yang J, Effect of Heat Stress During Meiosis on Grain Yield of Rice Cultivars Differing in Heat Tolerance and Its Physiological Mechanism. Acta Agronomica Sinica $2008,34,2134-2142$.

[43]Yang J, Chen X, Zhu C, Peng X, He X, Fu J, Ouyang L, Bian J, Hu L, Sun X, Xu J, He H, RNA-seq reveals differentially expressed genes of rice (Oryza sativa) spikelet in response to temperature interacting with nitrogen at meiosis stage. BMC Genomics 2015, 16, 959.

[44]Endo M, Tsuchiya T, Hamada K, Kawamura S, Yano K, Ohshima M, Higashitani A, Wanatabe M, Kawagishi-Kobayashi M, High Temperatures Cause Male Sterility in Rice Plants with Transcriptional Alterations During Pollen Development. Plant Cell Physiol 2009, 50, 1911-1922.

[45]Kim S T, Cho K S, Jang Y S, Kang K Y, Two-dimensional electrophoretic analysis of rice proteins by polyethylene glycol fractionation for protein arrays. Electrophoresis 2001, 22, 2103-2109.

[46]Bradford $\mathrm{M}, \mathrm{A}$ rapid and sensitive method for the quantitation of microgram quantities of protein utilizing the principle of protein-dye binding. Anal Biochem 1976, 72, 248-254.

[47]Liao J, Huang Y, Genomics, Evaluation of Protocols Used in 2-D Electrophoresis for Proteome Analysis of Young Rice Caryopsis. Proteomics and Bioinformatics 2011, 9, 229-237.

[48]Liao J, Zhou H, Zhang H, Zhong P, Huang Y, Comparative proteomic analysis of differentially expressed proteins in the early milky stage of rice grains during high temperature stress. J Exp Bot 2014, $65,665-671$.

[49]Zhang H, Lei G, Zhou H, He C, Liao J, Huang Y, Quantitative iTRAQ-based proteomic analysis of rice grains to assess high night temperature stress. Proteomics 2017, 17, 1600365.

[50]Yang Q, Wang Y, Zhang J, Shi W, Qian C, Peng X, Identification of aluminum-responsive proteins in rice roots by a proteomic approach: Cysteine synthase as a key player in Al response. Proteomics 2007, 7, 737-749.

[51]Nisha S, Neha J, Ram K, Ajay J, Nagendra K S, Vandna R, A Comparative Method for Protein Extraction and 2-D Gel Electrophoresis From Different Tissues of Cajanus Cajan. Front Plant Sci 2015, 6, 606.

[52]Olson B J, Markwell J, Assays for determination of protein concentration. Curr Protoc Pharmacol 2007, Appendix 3: 3A. 
[53]Ellis R J, The most abundant protein in the world. North-Holland Biomedical press, 1979.

[54]Meyer Y, Grosset J, Chartier Y, Cleyet-Marel J C, Preparation by two-dimensional electrophoresis of proteins for antibody production: antibodies against proteins whose synthesis is reduced by auxin in tobacco mesophyll protoplasts. Electrophoresis 1988, 9, 704-12.

[55]Rodrigues S P, Ventura J A, Zingali R B, Fernandes P M B, Evaluation of Sample Preparation Methods for the Analysis of Papaya Leaf Proteins Through Two-Dimensional Gel Electrophoresis. Phytochem Analysis 2009, 20, 456-464.

[56]Molloy M P, Two-dimensional electrophoresis of membrane proteins using immobilized pH gradients. Anal Biochem 2000, 280, 1-10.

[57]Des Francs C C, Thiellement H, de Vienne D, Analysis of Leaf Proteins by Two-Dimensional Gel Electrophoresis: Protease Action as Exemplified by Ribulose Bisphosphate Carboxylase/ Oxygenase Degradation and Procedure to Avoid Proteolysis During Extraction. Plant Physiol 1985, 78, 178-182.

[58]Van Etten J L, Freer S N, McCune B K, Presence of a Major (Storage ) Protein in Dormant Spores of the Fungus Botryodiplodia theobromaet. J Bacterio/ 1979, 138, 650-652.

[59]Schuster A M, Davies E, Ribonucleic Acid and Protein Metabolism in Pea Epicotyls : Il. Response to Wounding in Aged Tissue. Plant Physiol, 1983, 73: 817-821.

[60]Chen H, Zhao H, Yang T, Ruan S, Wang H, Xiang N, Zhou H, Li Q, Diao X, Comparative evaluation of five protocols for protein extraction from stony corals (Scleractinia) for proteomics. Electrophoresis 2018, $0,1-9$.

\section{Tables}

Table 1 Total protein concentrations and the number of protein spots

\begin{tabular}{clcc}
\hline Lane & Extraction & Total protein concentrations & $\begin{array}{c}\text { Number of } \\
\text { protein spots }\end{array}$ \\
\hline A & Phenol extraction & $13.59 \pm 0.057$ & $400 \pm 89$ \\
B & Mg/NP-40 extraction & $13.02 \pm 0.61$ & $422 \pm 37$ \\
C & Tris-Base/acetone extraction & $10.89 \pm 0.46$ & $424 \pm 66$ \\
D & SDS extraction & $10.76 \pm 0.17$ & $287 \pm 31$ \\
E & TCA/acetone/phenol extraction & $9.79 \pm 0.23$ & $450 \pm 53$ \\
F & TCA/acetone precipitation & $5.93 \pm 0.22$ & $321 \pm 17$ \\
\hline
\end{tabular}

* Total protein concentrations and the number of protein spots were described by mean value of triplicates \pm standard deviation (SD). 


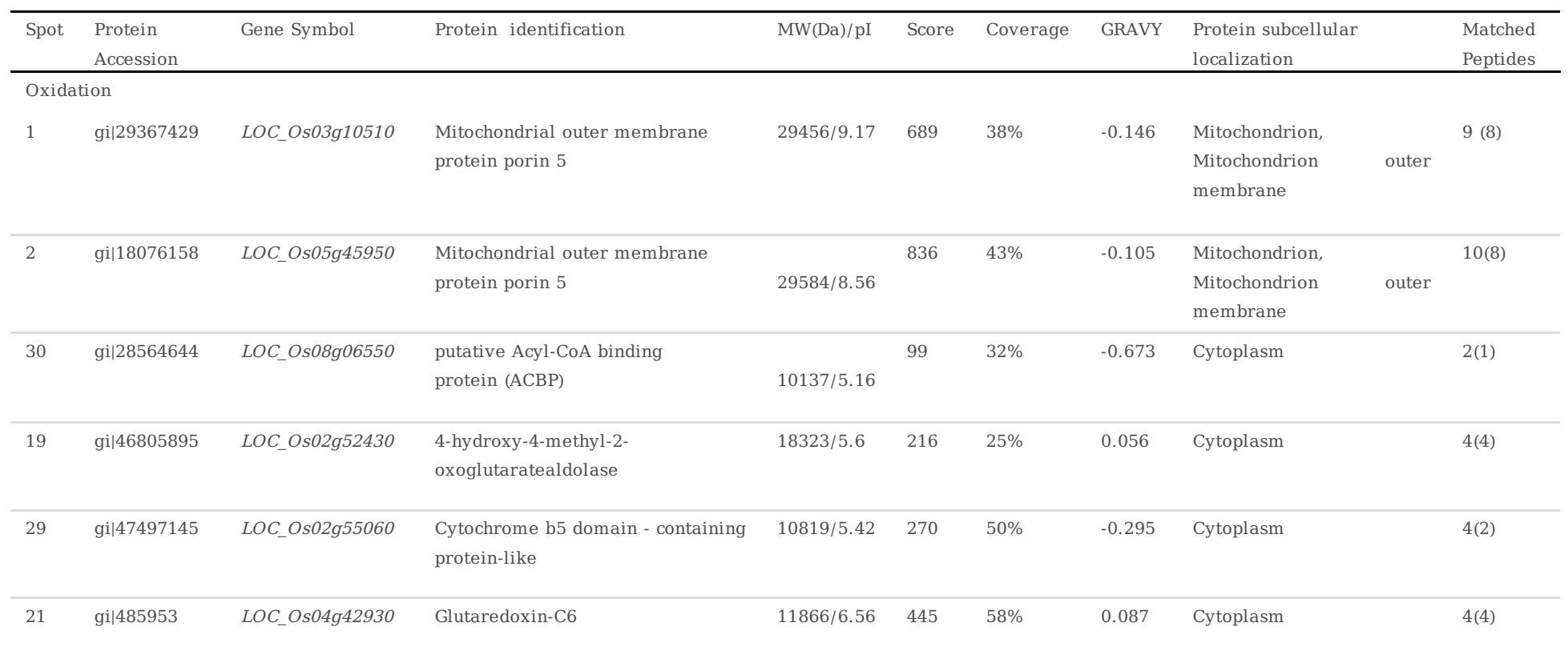

\section{Photosynthesis}

$4 \quad$ gi|11955 rbcL

Ribulose bisphosphate carboxylas 53421/6.13 $107 \quad 7 \%$

large chain

Biosynthesis

\begin{tabular}{|c|c|c|c|c|c|c|c|c|c|}
\hline 6 & gi|2058273 & LOC_Os09g31180 & 60S ribosomal protein L9 & $21406 / 9.62$ & 547 & $35 \%$ & -0.217 & Cytoplasm & $7(7)$ \\
\hline \multirow[t]{2}{*}{7} & gi|39545864 & & OSJNba0093F 12.16 protein & $17851 / 9.23$ & 335 & $25 \%$ & -0.228 & Cytoplasm & $3(3)$ \\
\hline & & LOC_Os04g50990 & & & & & & & \\
\hline 27 & gi|55296630 & LOC_Os06g05880 & putative profilin & $14352 / 4.73$ & 282 & $32 \%$ & -0.086 & Cytoplasm, Cytoskeleton & $4(4)$ \\
\hline 22 & gi|50725625 & LOC_Os08g02340 & $\begin{array}{l}\text { putative acidic ribosomal protein } \\
\text { P1a }\end{array}$ & $11133 / 4.43$ & 334 & $68 \%$ & 0.181 & Cytoplasm & $4(4)$ \\
\hline 10 & gi|55296170 & LOC_Os06g04290 & 40S subunit ribosomal protein & $14151 / 9.48$ & 152 & $18 \%$ & -0.303 & Cytoplasm & $3(3)$ \\
\hline
\end{tabular}

Unknown protein

\begin{tabular}{|c|c|c|c|c|c|c|c|c|c|}
\hline 11 & gi|125537087 & OsI_38785 & hypothetical protein OsI_38785 & $16976 / 8.26$ & 230 & $36 \%$ & -0.147 & Vacuoles; Cytoplasm & $4(4)$ \\
\hline \multicolumn{10}{|c|}{ Translation } \\
\hline 12 & gi|18461185 & LOC_Os01g48280 & $\begin{array}{l}\text { Putative ubiquitin-conjugating } \\
\text { enzyme E2 }\end{array}$ & $17206 / 6.74$ & 215 & $33 \%$ & -0.286 & Nucleus & $5(4)$ \\
\hline 13 & gi|108711192 & LOC_Os03g55150 & $\begin{array}{l}\text { Eukaryotic translation initiation } \\
\text { factor } 5 \mathrm{~A}\end{array}$ & $17930 / 5.87$ & 602 & $48 \%$ & -0.463 & Cytoplasm & $7(7)$ \\
\hline 17 & gi|303835 & LOC_Os11g43900 & $\begin{array}{l}\text { Translationally-controlled tumor } \\
\text { protein homolog }\end{array}$ & $18991 / 4.51$ & 593 & $60 \%$ & -0.383 & Cytoplasm & $8(8)$ \\
\hline 14 & gi|77555893 & LOC_Os12g32240 & $\begin{array}{l}\text { Eukaryotic translation initiation } \\
\text { factor } 5 \mathrm{~A}\end{array}$ & $17774 / 5.6$ & 868 & $57 \%$ & -0.497 & Cytoplasm & $8(8)$ \\
\hline
\end{tabular}


Transcriptional regulation

\begin{tabular}{|c|c|c|c|c|c|c|c|c|c|}
\hline 15 & gi|108707099 & LOC_Os03g13800 & $\begin{array}{l}\text { NHP2-like protein 1, putative, } \\
\text { expressed }\end{array}$ & $14037 / 6.56$ & 82 & $14 \%$ & -0.013 & Nucleus & $2(0)$ \\
\hline 20 & gi|22831338 & LOC_Os07g30090 & Actin-depolymerizing factor 9 & $16280 / 5.52$ & 49 & $6 \%$ & -0.525 & Cytoplasm, Cytoskeleton & $2(1)$ \\
\hline
\end{tabular}

Defense response

\begin{tabular}{|c|c|c|c|c|c|c|c|c|c|}
\hline 16 & gi|21741225 & LOC_Os04g39150 & OSJNBb0048E02.12 protein & $17256 / 4.75$ & 563 & $63 \%$ & -0.25 & Cytoplasm & $9(8)$ \\
\hline 24 & gi|3603473 & OSIGBa0125M19.3 & Elicitor-responsive protein 3 & $15973 / 4.22$ & 51 & $9 \%$ & -0.468 & Cytoplasm & $1(1)$ \\
\hline 18 & gi|29467522 & LOC_Os08g03520 & Cold shock domain protein 2 & $19024 / 6.28$ & 119 & $9 \%$ & -0.724 & Mitochondrion & $1(1)$ \\
\hline
\end{tabular}

Transportion and signal transduction

\begin{tabular}{|c|c|c|c|c|c|c|c|c|c|}
\hline 23 & gi|20188 & $C A M 1-1$ & calmodulin & $16878 / 4.11$ & 587 & $51 \%$ & -0.619 & Nucleus & $1(1)$ \\
\hline 26 & gi|29367559 & LOC_Os08g02420 & putative serine / threonine kinase & $16672 / 4.89$ & 581 & $56 \%$ & -0.411 & Cytoplasm & $8(7)$ \\
\hline 28 & gi|5360221 & LOC_Os08g42000 & nuclear transport factor 2 (NTF2) & $13459 / 5.33$ & 65 & $6 \%$ & -0.129 & Cytoplasm & $1(1)$ \\
\hline
\end{tabular}

\section{Figures}

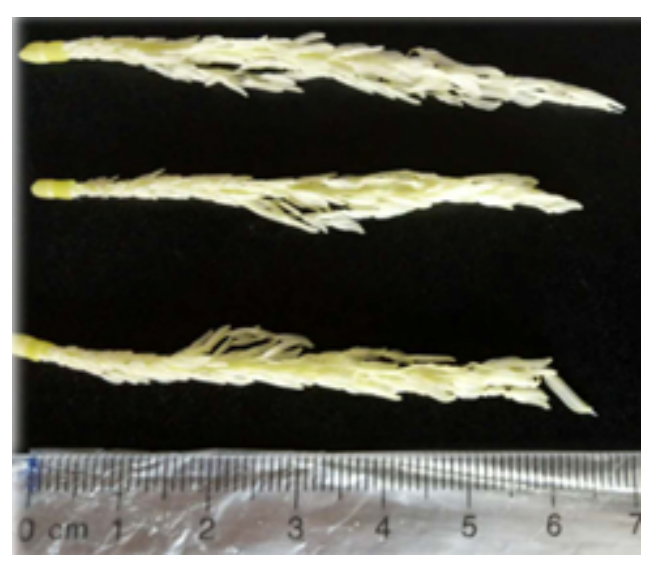

Figure 1

Rice young panicles in $7 \mathrm{~cm}$. 


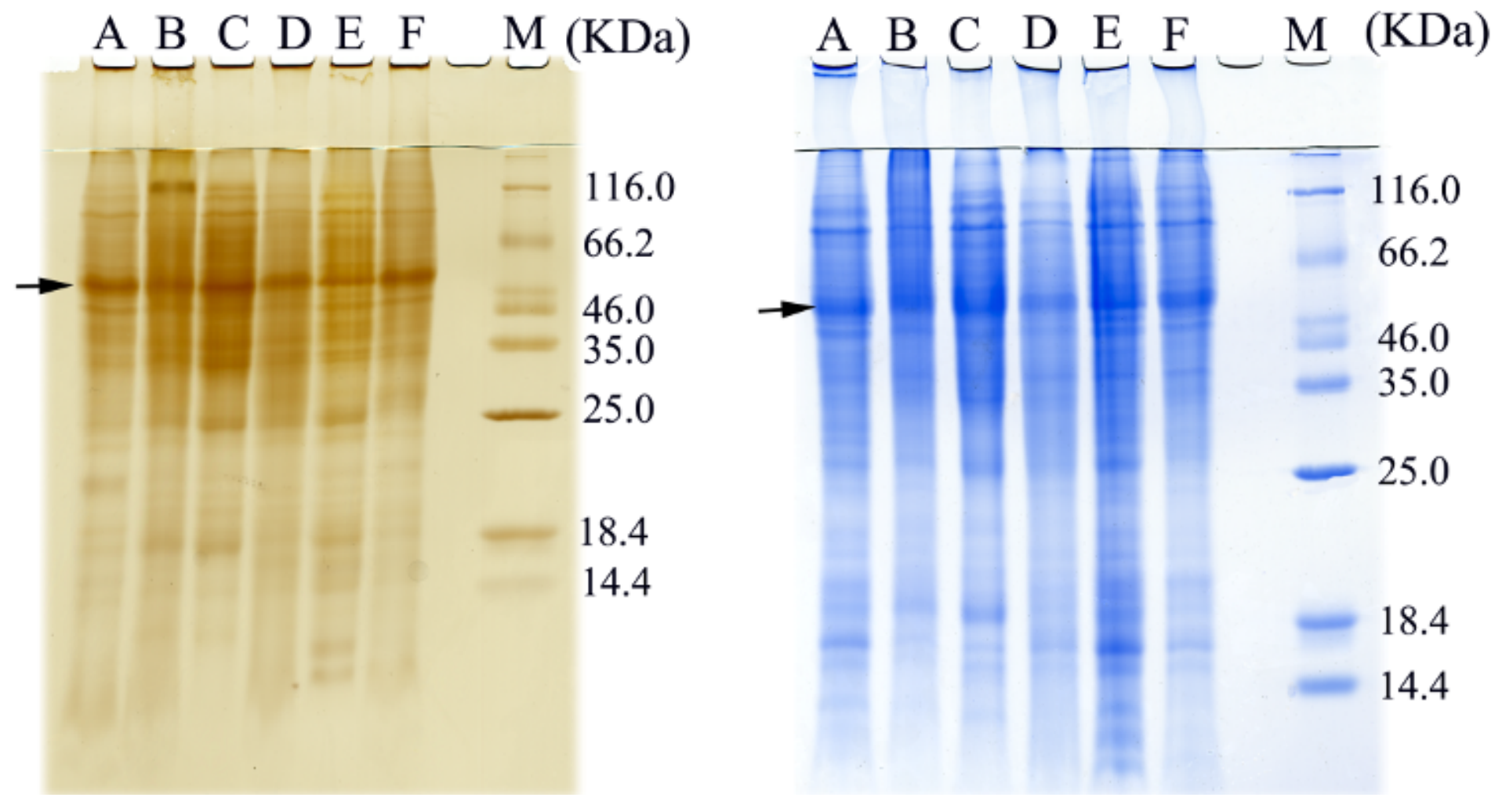

Figure 2

SDS-PAGE gel images of protein extracted from rice young panicles using six protocols. (A) Phenol extraction; (B) Mg/NP-40 extraction; (C) Tris-Base/acetone extraction; (D) SDS extraction; (E) TCA/acetone/phenol extraction; (F) TCA/acetone precipitation, M: marker. 36 micrograms of total protein each protocol were loaded per lane. Gels were stained with CBB G-250 (right) and silver stained (left), respectively. 


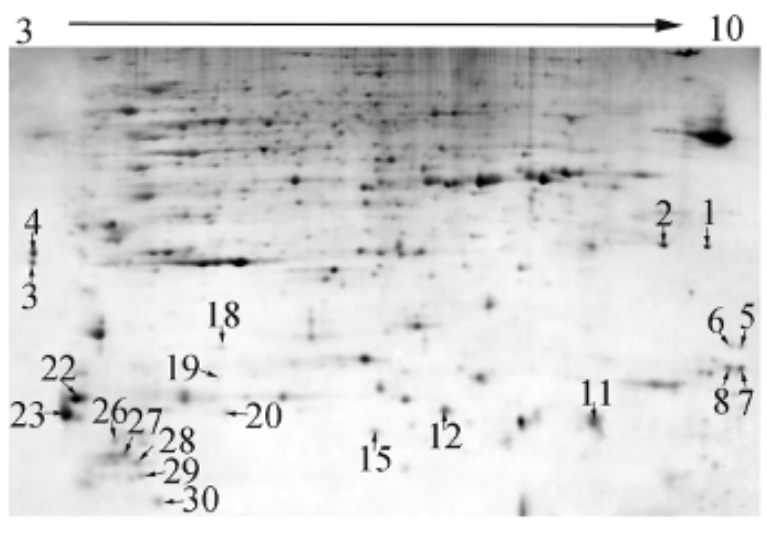

A

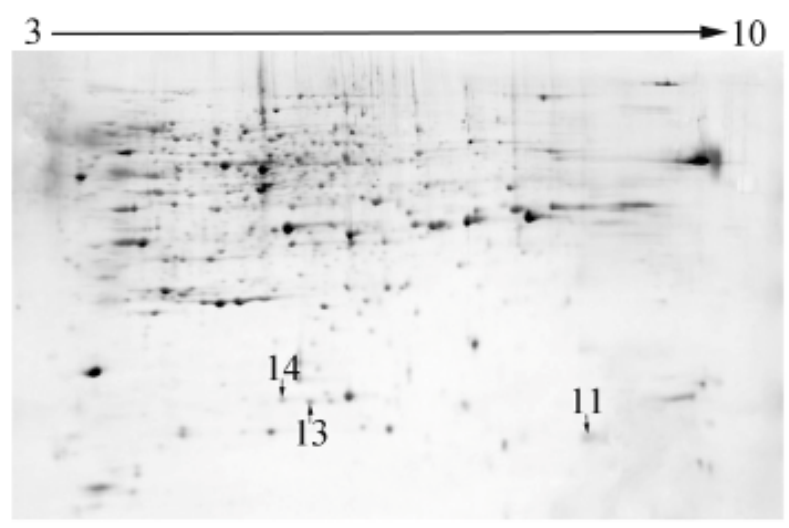

$\mathrm{C}$

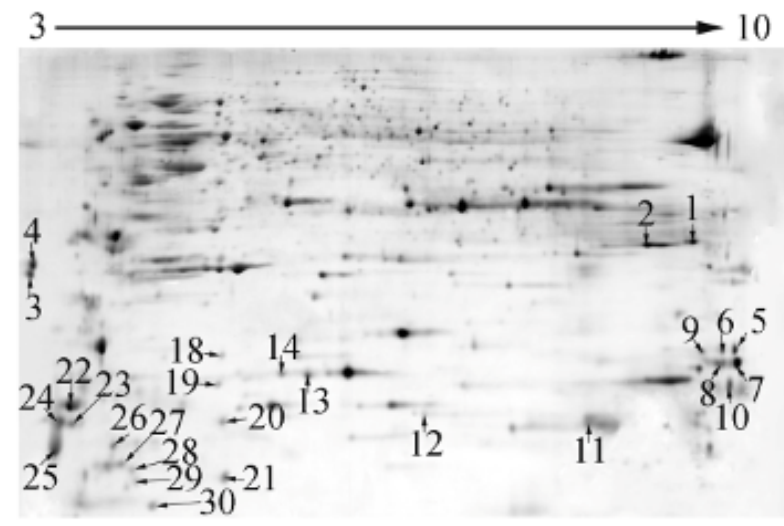

E

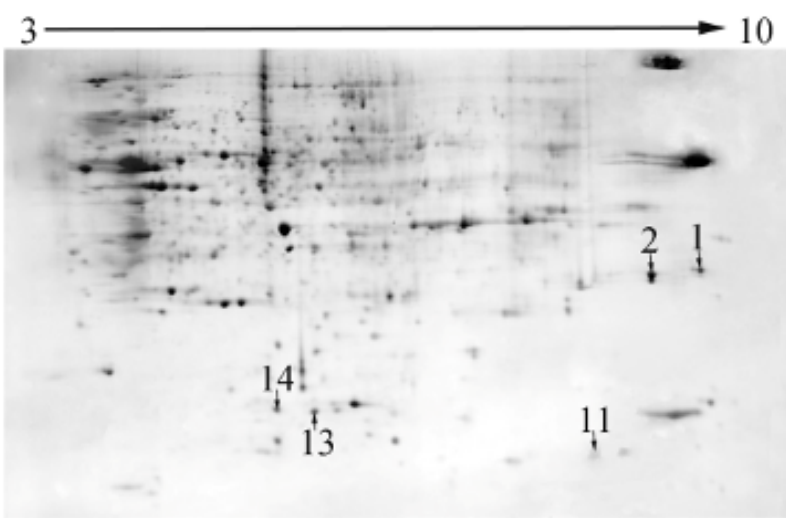

B

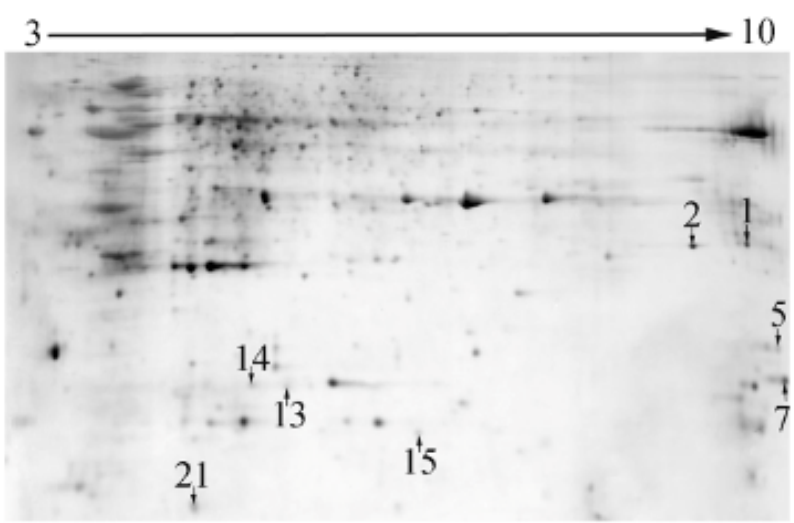

$\mathrm{D}$

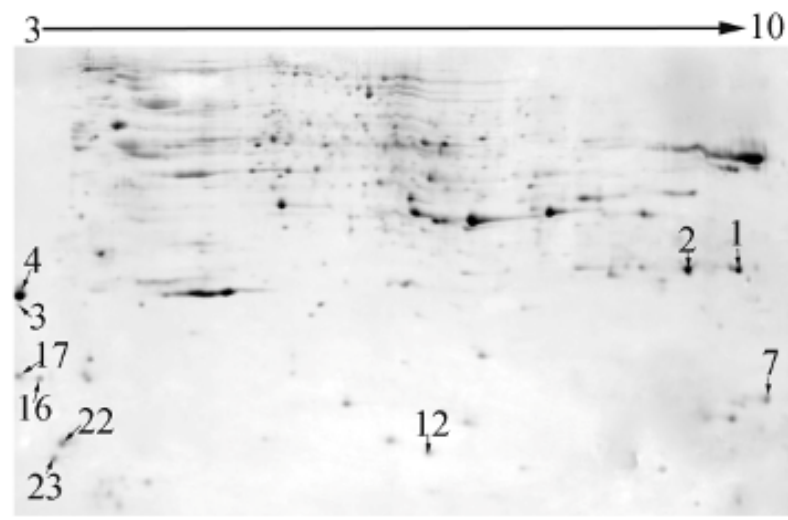

$\mathrm{F}$

\section{Figure 3}

Representative 2-DE gel images of protein respectively extracted from rice young panicles by six protocols. (A) Phenol extraction; (B) Mg/NP-40 extraction; (C) Tris-Base/acetone extraction; (D) SDS extraction; (E) TCA/acetone/phenol extraction; (F) TCA/acetone precipitation. $250 \mu \mathrm{g}$ protein of each protocol was separated on 12.5\% SDS-PAGE gel with $24 \mathrm{~cm}$ nonlinear IPG strips pH 3-10. The gels were 
silver stained. Differential extracted proteins presented in either one protocol or less than six protocols were indicated by arrows.
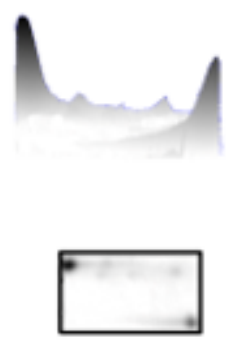

A
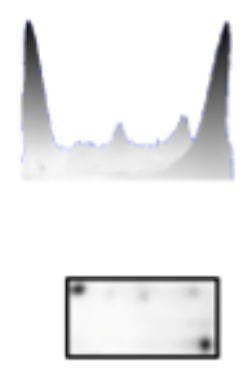

$\mathrm{D}$
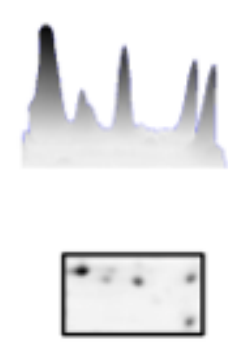

$\mathrm{B}$
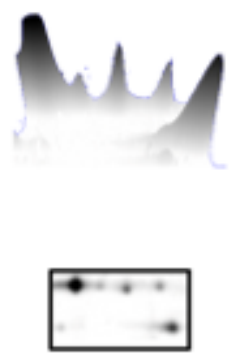

$\mathrm{E}$
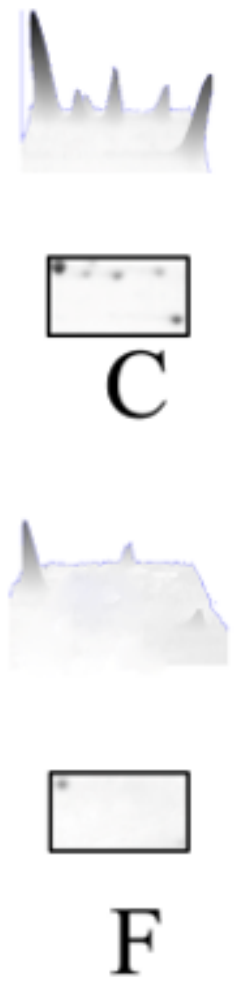

\section{Figure 4}

The abundance of same protein respectively extracted by six protocols. (A) Phenol extraction; (B) Mg/NP40 extraction; (C) Tris-Base/acetone extraction; (D) SDS extraction; (E) TCA/acetone/phenol extraction; (F) TCA/acetone precipitation The larger and darker of protein spots indicated the higher abundance. 